Удк: 316.012

DOI: https://doi.org/10.32689/2617-

2224-2019-18-3-473-489

\section{Тертичний Олександр Васильович,} незалежний дослідник, координатор групи “Спільний Проект”, 03134, Київ, вул. Симиренка, 13/1, тел.: +38 (093) 57098 48, e-mail:tertychnyi@gmail.com

ORCID: 0000-0003-4034-5196

Тертычный Александр Васильевич, независимый исследователь, координатор группь “Спильный Проект", 03134, Киев, ул. Симиренко, 13/1, тел.: +38 (093) 570 98 48, email:tertychnyi@gmail.com

ORCID: 0000-0003-4034-5196

\section{Tertychnyi Oleksandr Vasyliovych,}

Independent Scholar, Coordinator of the Joint Project Group, 03134, Kyiz, Str. Symyranka, 13/1, tel.: +38 (093) 57098 48, e-mail: tertychnyi@gmail.com

ORCID: 0000-0003-4034-5196

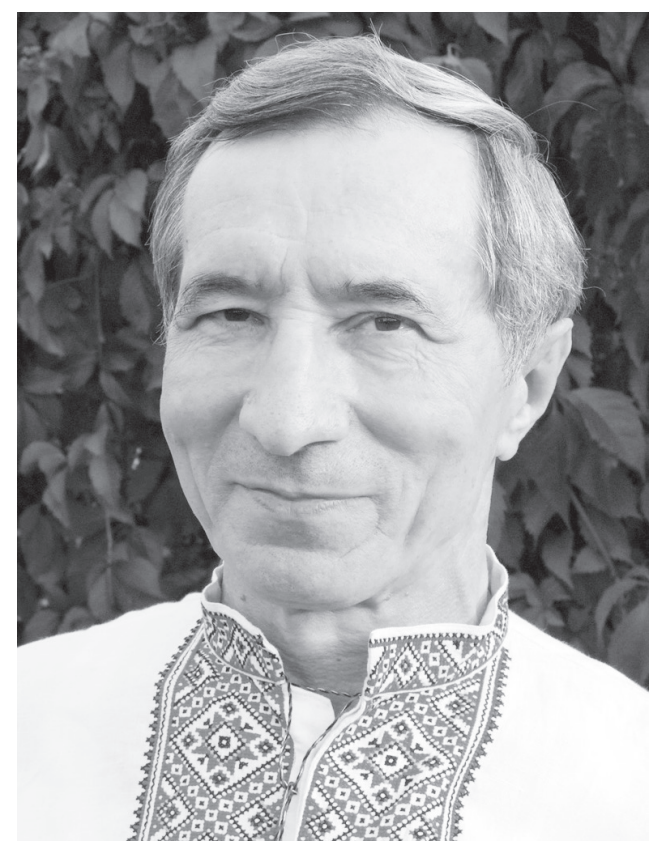

\title{
УКРАЇНСЬКИЙ АРХЕТИП І ЄВРОПЕЙСЬКА БЕЗПЕКА
}

Анотація. Публікація виходить 3 того, що руйнування світової системи безпеки стало як ознакою, так і наслідком новітньої кризи Заходу. Із усієї сукупності причин увагу авторів привертають втрата орієнтирів і сенсів, відхід від базових цінностей, розм'якшення норм і табу. Наслідком стало небезпечне зменшення суспільної довіри, на якій, власне, і грунтуються демократії.

Як відомо, в таких умовах сподівання багатьох західних інтелектуалів звернулися до України: “Сьогодні український Майдан представляє Європу в найкращому вигляді... Дозвольте нам допомогти українцям побудувати нову Україну - i тоді вони, безумовно, допоможуть нам побудувати нову Європу і більш справедливий світ".

Так Майдан поєднав два історичних процеси: оздоровлення українського суспільства і традиційних демократій. ФУНДАМЕНТАЛЬНИХ європейських цінностей прагнули як українці, так і європейські інтелектуали, але процес оновлення загальмувався: результати п’яти років не влаштовують ні українців, ні європейців. В Україні головним гальмом стала феодально-олігархічна система, докорінна перебудова якої є першою передумовою перемоги над агресором та відновлення територіальної цілісності й державного суверенітету, як написав у 2016 р. перший віце-президент НАН України, 
директор Національного інституту стратегічних досліджень Володимир Горбулін.

Аналогічного висновку раніше дійшли громадяни, які у 2012 р. заснували міждисциплінарну групу незалежних дослідників “Спільний Проект”. Група висунула концепт деолігархізації і сталого розвитку, який виходить 3 того, що оновлення країни можливе лише за масової підтримки громадян. Вони мають отримати привабливу і правдиву перспективу розвитку країни та Національну Дорожню карту. Подібної перспективи чинні реформатори не мають, масової підтримки не отримали, що, зокрема, засвідчив і програш українського політикуму “новому обличчю” на виборах президента 31 березня $2019 \mathrm{p}$.

Протягом 2012-2017 рр. “Спільний Проект” змоделював концепт Позитивного сценарію, який передбачає й обгрунтовує таку перспективу. Агенція досліджень системних технологій надала рецензію на Документ, де зазначила, зокрема, що Позитивний сценарій може бути рекомендований як проект програми об'єднавчої платформи.

Публікація привертає увагу до тих фрагментів сценарію, які відображають схожі риси українських і західноєвропейських процесів, отже, відкривають можливі напрями співпраці українських та іноземних дослідників.

Ключові слова: український архетип, ентелехія, мережана демократія, персональний мандат, “жовті жилети”, публічна соціологія, деолігархізація.

\section{УКРАИНСКИЙ АРХЕТИП КАК ИСТОЧНИК ЕВРОПЕЙСКОЙ БЕЗОПАСНОСТИ}

Аннотация. Публикация исходит из того, что разрушение мировой системы безопасности стало как признаком, так и следствием нового кризиса Запада. Из всей совокупности причин внимание авторов привлекают потеря ориентиров и смыслов, уход от базовых ценностей, размягчение норм и табу. Следствием стало опасное уменьшение общественного взаимодоверия, на котором, собственно, и основываются демократии.

Как известно, в таких условиях надежды многих западных интеллектуалов обратились к Украине: “Сегодня украинский Майдан представляет Европу в лучшем виде ... Позвольте нам помочь украинцам построить новую Украину - и тогда они, безусловно, помогут нам построить новую Европу и более справедливый мир”.

Так Майдан объединил два исторических процесса: оздоровление украинского общества и традиционных демократий. К ФУНДАМЕНТАЛЬНЫМ европейским ценностям стремились как украинцы, так и европейские интеллектуалы, но процесс обновления затормозился: результаты работы пяти лет не устраивают ни украинцев, ни европейцев. В Украине главным тормозом стала феодально-олигархическая система, коренная перестройка которой является первой предпосылкой победы над агрессором и восстановления территориальной целостности и государственного суверенитета - написал в 2016 г. первый вице-президент НАН Украины, директор 
Национального института стратегических исследований Владимир Горбулин.

К аналогичному выводу ранее пришли граждане, которые в 2012 г. основали междисциплинарную группу независимых исследователей “Спільний Проект”. Группа выдвинула концепт деолигархизации и устойчивого развития, который исходит из того, что обновление страны возможно только при массовой поддержке граждан. Они должны получить привлекательную и правдивую перспективу развития страны и Национальную Дорожную карту. Подобной перспективы действующие реформаторы не имеют, массовой поддержки не получили, что, в частности, показал и проигрыш украинского политикума “новому лицу” на выборах президента 31 марта 2019 г.

В течение 2012-2017 гг. “Спільний Проект” смоделировал концепт Позитивного сценария, который предсказывает и обосновывает такую перспективу. Агентство исследований системных технологий предоставило рецензию на документ, где отметило, в частности, что Позитивный сценарий может быть рекомендован как проект программы объединительной платформы.

Публикация привлекает внимание к тем фрагментам сценария, которые отражают сходные черты украинских и западноевропейских процессов, следовательно, открывают возможные направления сотрудничества украинских и иностранных исследователей.

Ключевые слова: украинский архетип, энтелехия, облачная демократия, персональный мандат, “желтые жилеты”, публичная социология, деолигархизация.

\section{UKRAINIAN ARCHETYPE AS A SOURCE OF EUROPEAN SECURITY}

Abstract. The publication proceeds from the fact that the destruction of the world security system has become both a sign and a consequence of the recent crisis in the West. Of the total set of reasons, the attention of the authors is attracted by the loss of landmarks and meanings, the departure from the basic values, softening of norms and taboos. The consequence was a dangerous reduction of public trust, which, in fact, is based on democracy.

As you know, in these circumstances, the hopes of many Western intellectuals appealed to Ukraine: "Today, the Ukrainian Maidan represents Europe at its best ... Let us help Ukrainians build a new Ukraine - and then they will certainly help us build a new Europe and a more just world".

So Maidan combined two historical processes: the improvement of Ukrainian society and traditional democracies. FUNDAMENTAL European values were sought by both Ukrainians and European intellectuals, but the process of renewal was slowed down: the results of five years do not suit either Ukrainians or Europeans. In Ukraine, the first vice president of the National Academy of Sciences of Ukraine, director of the National Institute for Strategic Studies Volodymyr Horbulin, wrote in 2016, the main brake became the feudal-oligarchic system, the radical restructuring of which is the first precondition for victory 
over the aggressor and the restoration of territorial integrity and state sovereignty.

Similar conclusion was previously arrived by citizens who in 2012 founded an interdisciplinary group of independent researchers of the Joint Project. The group has put forward the concept of de-oligarchy and sustainable development, which proceeds from the fact that the country's renewal is possible only with mass support of citizens. They should receive an attractive and true prospect of development of the country and the National Roadmap. The current reformers do not have a similar perspective, they did not receive mass support, which, in particular, showed Ukrainian politicians losing their "new face" in the presidential elections on March 31, 2019.

During 2012-17, the Joint Project modeled the Positive scenario, which provides and justifies this perspective. The System Technology Research Agency provided a review of the Document, which stated, in particular, that the Positive scenario could be recommended as a draft unification platform program.

The publication attracts attention to those Scenario fragments that reflect similar features of Ukrainian and Western European processes, and thus open up possible directions for cooperation between Ukrainian and foreign researchers.

Keywords: Ukrainian archetype, entelechy, network democracy, personal mandate, "yellow vests", public sociology, deoligarchy.

Постановка проблеми. 2010 року власник порталу Netzpolitik.org Маркус Бекедаль заявив, що провідні політики Німеччини проспали Інтернет, в якому народжується “п'ята влада”, і тепер політики мають навчитися спілкуванню з громадянським суспільством [1]. Авторська концепція виходить з обох аспектів діагнозу: соціальні мережі відкрили нову епоху цивілізації [2], а політикум не встигає реагувати на параболічне прискорення суспільного розвитку [3].

Руйнування світового безпекового простору логічно випливає наслідком внутрішньої кризи могутнього Заходу. Втрата орієнтирів i сенсів, відхід від базових цінностей та розм'якшення норм і табу привело до зменшення довіри в західних кра- їнах. Зниження довіри руйнує демократичні суспільства. Зокрема, президент США Барак Обама з трибуни Генеральної Асамблеї ООН 2016 року визнав: “...світ за багатьма мірками $є$ менш насильницьким і процвітає більше, ніж будь-коли раніше, тим не менше, наші суспільства сповнені невизначеності, занепокоєння та розбрату. Незважаючи на величезний прогрес, люди втрачають довіру до інституцій..." [4]

Відомою ознакою цього процесу стали масові протести, перша хвиля яких відбулася 2011 року: навесні і влітку Європою під гаслом REAL DEMOCRATIE YA, а восени та взимку у США під гаслом Оссиру Wall Street. Президент Міжнародної соціологічної асоціації Іммануель Валерстайн відзначив, що це була 
найважливіша політична подія $\mathrm{y}$ Сполучених Штатах від часів 1968 року... [5]

Від осені 2018 року не припиняються акції “жовтих жилетів”, які фактично продовжили хвилю 2011 р. Вони вже змусили президента Франції прийняти частину їхніх вимог, потім провести безпрецедентні національні дебати, аби "почути французів”. Але цього не вистачило, щоби припинити протести, і подальші події залишаються непередбачуваними.

Українська школа архетипіки пояснює цей процес 3 позицій універсального соціального циклу: "Суспільство перехідного стану (революції та коеволюції) переживає інституційні зміни, під час яких розмиваються соціальні структури й соціальні норми, соціальні зв'язки слабшають і навіть розриваються під час інверсії, порушується ієрархія факторів, які складають механізми відтворення соціальних структур" [6; 12].

Сподівання восьми десятків західних інтелектуалів звернулися до України: “Сьогодні український Майдан представляє Європу в найкращому вигляді - у такому, який багато мислителів минулого і сьогодення визначали фундаментальними європейськими цінностями...” [7].

На Майдані поєдналися два історичних процеси: оздоровлення українського i всеєвропейського суспільств. Фундаментальних європейських цінностей прагнули як українці, так і європейські інтелектуали.

Авторський концепт взяв до уваги зміну європейської диспозиції, яку
Бернар-Анрі Леві сформулював так: “Ця Європа наче скам'яніла під час Майдану, це Європа, яка не наважується підняти голос на Путіна - це Європа, яка залякана, боїться. Це Європа, яка вже не вірить сама в себе - звичайно, така Європа розчаровує. Отже існує ідея Європи, яку тепер несе в собі Україна...” [8]

Загальні контури успішної України і Дорожньої карти Спільний Проект презентував 2013 року на II Конгресі Соціологічної асоціації України [9]. Майдан підтвердив і наповнив реальним життям зазначений авторський концепт. Швейцарський економіст, колишній член Римського клубу, футуролог Богдан Гаврилишин пізніше підкреслював: "На Майдані не було конкуренції, але були створені всі потрібні служби: не за наказом уряду, а через почуття обов’язку перед своїми співгромадянами та країною... Ця мотивація є фантастична. Таким чином, наші люди вже почали діяти згідно з тою новою парадигмою, за якою повинен жити світ. Ми не мусимо у всьому доганяти світ - чи то Європу, чи то США... То дуже мало потрібно, щоби українське економічне диво почалося. Думаю, що початок може бути за два роки, але потрібні тотальні трансформації" [10].

На жаль, сподіваня на тотальні трансформації заблокувала феодально-олігархічна система. Перший віце-президент НАН України, директор Національного інституту стратегічних досліджень Володимир Горбулін наголосив 2016 р.: “Докорінна перебудова цієї системи $є$ першою передумовою перемоги над агресором та відновлення територі- 
альної цілісності й державного суверенітету" [11].

Авторський концепт виходить 3 того, що деолігархізацію України можливо провести лише за певного рівня взаємодовіри у суспільстві, за масової підтримки громадян. Вони мають отримати привабливу i обгрунтовану перспективу розвитку. Теоретично подібну перспективу мала би надати державна Стратегія, але в Україні її досі немає, то ж немає ні єднання, ні натхнення.

Аналіз останніх досліджень і публікацій. Реакцією на відсутність державної стратегії стала діяльність громадських “стратегаторів". Вони моделювали свої Бачення майбутнього, як “проектні завдання" - для наступного творення державної Стратегії. Висунули чимало оригінальних ідей, напрацювали багато цікавих концепцій. Але жодна не містить цілісної відповідності українському архетипу, історичній місії та прагненням нації [12].

Кількість візій зростає, а визначити з них кращу досі не вдалося. У відповідь на таку невизначеність на V семінарі TMC 2014 року третя група динамічної мережі рекомендувала СТРАТЕГІЮ ВИХОДУ УКРАЇНИ IЗ СИСТЕМНОÏ КРИЗИ [13], яка складається з 12 тез. № 1: формування Стратегії має розпочинатися з визначення суспільно прийнятної Мети розвитку України в осяжному майбутньому. Десять тез надають опорні репери першої редакції Позитивного сценарію Спільного Проекту.

Наступного 2015 року Указом Президента України була ухвалена Стратегія сталого розвитку "Украї- на - 2020". На жаль, документ не відповідає назві: по суті це пакет неструктурованих за пріоритетами намірів та побажань. Зокрема, рух уперед було передбачено за чотирма векторами і одночасно реалізувати 62 реформи та програми. Метою Стратегії було оголошено протягом 5 років “впровадження в Україні європейських стандартів життя та вихід України на провідні позиції у світі" [14]. Необгрунтованість тих намірів засвідчила практика.

Дослідницька спільнота "Foundation for Future" (fff) взяла методологічною основою договірний принцип. Створений за її провідною участю проект Суспільного договору містить багато цікавих ідей і корисних новацій. Але питання суб'єкта реалізації Договору в документах залишається відкритим, як і в інших “візіонерів" [15].

Під науковим керівництвом академіка НАН України М. Згуровського 2015 року створено масштабний “Форсайт економіки України”. Документ містить глибокий аналіз, багато корисних передбачень і рекомендацій. Горизонтом на 2030 рік вірогідність сценаріїв майбутнього Форсайт визначив песимістично: "Чужа суб'єктність” - близько 30 \%, "Сipa зона" - 15-18 \%, "Дезінтеграція" близько $5 \%$, збалансованого розвитку (позитивний варіант) - 2 \%. Разом 3 тим, Форсайт залишає сподівання на реалізацію найменш вірогідного сценарію "збалансований розвиток": завдяки народу України, передбачити дії якого неможливо [16, с. 136].

Автори визнали обмеженість технологічного передбачення, з чого випливає потреба звернення до футу- 
ристичних методів. Ту ж потребу, вже 2018 року, визнав перший віце-президент НАН України, директор Національного інституту стратегічних досліджень Володимир Горбулін, коли закликав “дати хоч якийсь зрозумілий і футуристично прийнятний орієнтир" [17].

Особливу увагу привертають напрацювання Української школи архетипіки. Чимало iï аксіом, спостережень і висновків співпадають 3 деякими вузлами авторського Бачення. Обидва напрями, принаймні частково, грунтуються на метафізичних концептах, обидва підкреслюють нову, суб'єктну роль особи, обидва прийшли до оптимістичного передбачення Майбутнього України.

Разом з тим, Позитивний сценарій від початку створювався як науково-дослідницький проект (за теорією Імре Лакатоша). I тому передбачення Спільного Проекту стали лише базою для подальшого напрацювання методів поточного цілеспрямованого впливу на майбутнє. Авторське бачення Ukrainian dream [18] стало лише одним з важливих вузлів у процесі пошуку спільної Мети, Дорожньої карти і соціального суб'єкта.

Метою статті є окреслення можливостей поширення цінностей Майбутнього і практичного досвіду Майдану (“майданного” архетипу) для творення консолідованої системи безпеки і сталого розвитку: як в Україні, так і в європейських країнах. Важливою умовою успіху передбачається демонтаж олігархічної системи, яка загрожує існуванню суверенної України.

Виклад основного матеріалу дослідження. Від початку 2015 року публічне адміністрування в Україні спрямоване на перебудову Системи. Створені нові інституції, до керівництва державними органами запросили визнаних професіоналів та іноземних фахівців, донори і кредитори профінансували громадських активістів і медійну підтримку. Наявні певні результати: суттєво "очищений” НАК "Нафтогаз України", реформується адміністративна служба і банківський сектор, створена патрульна поліція, система державних закупівель...

Проте, більша частина нововведень виявилася традиційною імітацією. Очищення, люстрацію та конкурси на заміщення посад провели довірені люди, пов'язані спільними інтересами та взаємними зобов'язаннями в минулому. Оновлення структур відбувається настільки повільно, що дає час Системі “перемолоти” нових, позасистемних людей: купити, залякати, витиснути на манівці.

"Нас використали" - визнали представники низки громадських організацій під орудою “Автомайдану”, які взялися контролювати атестацію працівників поліції. Слідом аналогічну заяву оприлюднила Громадська рада доброчесності, яка не впоралася з очищенням судової корпорації.

Помилковість такого курсу засвідчило найбільше зниження довіри українців до влади (до 9 \% [19]), і гучна поразка представників українського політикуму на президентських виборах 31 березня 2019 року. Більше 30 відсотків голосів, які отримало “нове обличчя", очевидно були не голосами 3А невідомого кандидата-неофіта, а протестом ПРОТИ зниження рівня життя, провалу ан- 
тикорупційної кампанії і зневаги до суспільства з боку владних структур після революції Гідності.

До висновку про помилковість поточної політики вже прийшли i деякі її прихильники і учасники. Досить авторитетні експерти прямо вказали: “...серед деяких міжнародних агентств і урядів країн-донорів, включно з їх посольствами у Києві, панує доволі поверхове уявлення про корупцію в Україні” [20]. Автори сподіваються, що Захід змінить свою політику щодо України на “правильну”, але недооцінюють внутрішньої суперечливості своїх сподівань. Бо, в тій же цитованій статті цілком справедливо зазначено що державні інститути не представляють інтересів громадян, які, своєю чергою, їм не довіряють.

Так 2019 року реформатори нарешті підійшли до проблеми, яка була оприлюднена п'ятьма роками раніше вельми компетентною особою - Андрієм Єрмолаєвим. Він напередодні залишив посаду керівника Національного інституту стратегічних досліджень, і публічно заявив: державні інститути в Україні приватизовано [21]. Тобто, у реформаторів є об'єкт, але немає суб'єкта реформування.

Для незалежних дослідників проблема була очевидною давно, і 2012 року для пошуку іï вирішення було створено міждисциплінарну групу Спільний Проект. Група напрацювала Позитивний сценарій, який отримав прихильну рецензію Агенції досліджень системних технологій [22].

Позитивний сценарій як модель публічної сочіологіï. Звернення громадянських активістів до проблем соціальної філософії і футурології стало суспільною реакцією на обмеженість домінуючої форми соціологічного мислення, як визначив соціолог Ю. Яковенко [23]. Громадські ж дослідники не залежать від держави та ринку, вільні у виборі предмета і методів. Зокрема, вони не відчувають тиску наукових авторитетів, не пов'язані консервативними формами і умовностями, мають можливість i мають потребу у публічному форматі. Це дає можливість долати специфічні обмеження як “професійної, так і “прикладноі” соціології.

Вельми специфічним у “візіонерів” був і предмет дослідження: стратегічна Мета України і Дорожня карта до неї. Аби “охопити неоглядне”, Спільному Проекту довелося керуватися принципом мінімальної достатності, який став основою методологіï ad hok (для цього випадку). Спочатку виявили мінімум ключових реперів історичного процесу, i винесли за дужки все інше: аби зберегти від розриву граничний контур, що окреслив суть і забезпечив цілісність концепту. Фактично цей метод є стислим варіантом принципу мінімального універсуму.

Умова завершеності концепту потребувала піднести логічний ланцюжок пошуку до стратегічної української Мети, і (зворотним шляхом) дійти до конкретної відповіді на практичне запитання: що робити сьогодні?

Разом з тим, аби побачити Візію, треба було розуміти сутність Мети, а іiї неможливо сформулювати поза баченням історичного обрію. 3 іншого боку, Мета стане досяжною, якщо спиратиметься не лише на прогнози, 
але й на базис, котрий вже існує чи потребує розробки. Щоб зрозуміти цілісність Візії, треба з'ясувати значення її складових, але й складові, окремо у своєму розумінні та призначенні, стають відкритими лише за умови зрозумілості гештальтних особливостей Візії [24].

Таким чином коло замкнулося: реалізація Візії потребує суб'єкта суб'єкт потребує Програми - Програма має грунтуватися на візійній Платформі.

Соціальний суб'єкт модернізаціі. Носіями новітнього "майданівського” архетипу орієнтовно можна вважати від 3 до 10 відсотків українців. Нижча межа - частка волонтерів [25], вища - частка учасників майданів. Тримаючи східний форпост $\mathrm{i}$ надихаючи сподіваннями втомлену Європу, вони мають дбати і про наступну проблему: піднесення соціально-економічного та технологічного розвитку країни.

Більшість соціологів і політологів пов'язують сподівання на модернізацію із середнім класом. Він давно вважався основою західної демократії, зокрема, і тому, що прагнення особистої свободи у його представників переважало прагнення багатства i влади. Проте, з часом виникає дедалі більше питань, які ставлять під сумнів роль "гегемона демократії".

Український центр економічних і політичних досліджень імені О. Разумкова визначив такі соціально-класові групи: вищий клас $1 \%$; середній клас - $14 \%$; периферія середнього класу - 35 \%; нижчий клас $-31 \%$. Відсотки свідчать, що виявлений середній клас посідає незвичну для традиції позицію ви- щого класу, оскільки 1 \%, очевидно, становлять представники крупного капіталу. А серединну позицію (наступні 35 \%) посідає населення, яке віднесено до ПЕРИФЕРІЇ класу: за методикою Центру їхній матеріальний статок, якість освіти і культури та реальний статус у суспільстві не сягають показників “кондиційного” середнього класу.

Наш середній клас НЕ є носієм i захисником демократії, а лише має бути. Він відіграє роль соціального стабілізатора, тобто консерватора Системи, але НЕ має ознак волелюбства. Автори нагадують, що у цьому разі можна погодитися з деякими дослідниками, які вважають, що середній клас далеко не завжди в суспільстві відігравав прогресивну роль [26].

Тим часом, як припускає Спільний Проект, Майдан та війна започаткували в Україні новий соціальний прошарок - відповідальний. За традицією, волелюбну спільноту, що формується, автори концепту визначають терміном “клас". Його специфіка полягає, зокрема, в тому, що основу становлять суто українські соціальні спільноти: майданівці, добровольці та волонтери. Їхні інтереси збігаються з вектором перспективного розвитку суспільства, який пропонує Позитивний сценарій.

Увагу на важливу рису цього класу звертають деякі психологи: після фронту добровольців намагаються повернути в те життя, проти якого вони боролися на війні: та ж корупція, злодійство, соціальна несправедливість тощо. 3 цим новим/старим життям більшість ветеранів вже ніколи не погодяться. 
Сценарій бере до уваги, що волелюбний клас перебуває на стадії формування і самоусвідомлення. Саме зараз інтелектуали можуть відіграти “інженерну” функцію його формування - відповідно до переходу від стану “класу в собі” до стану “класу для себе”. На подібну трансформацію іншого (середнього) класу сподіваються дослідники УЦЕПД.

Варто нагадати, що професор Майкл Буравой зазначав: публічна соціологія передбачає участь у створенні та трансформації громадських структур [27]. Саме так i вчинив Спільний Проект, коли виявляв і поширював інформацію про специфічні інтереси і цінності відповідального класу, відмінності чи збіги з інтересами інших спільнот.

\section{Об'єднавча платформа суб'єк-} ma. Проектом програми суб'єкта модернізації має стати Бачення (Biзія) майбутнього та Дорожня карта. Найбільш суттєвими аспектами Сценарію є зосередження уваги на концепції Єдиної Візіі (спільного бачення) майбутнього України і методологія творення Стратегії та Програми здійснення реформ [28]. Як стартовий пакет оновлення країни, 2017 р. Сценарій запропонував висунути об'єднавчий мем “персональний мандат”. Це правова новація, яка призначена передати реальний контроль за обраними особами безпосередньо до рук громадян. Голос, який був поданий за кандидата чи партію, кожен виборець має отримати змогу відкликати до завершення поточної каденції. Якщо обранець умови політичного кредитування не виконує (наприклад, голосує всупереч обі- цянкам), він порушує умови цільового використання кредиту. Отже, займодавець-виборець має підстави припинити кредитування в той момент, коли пересвідчився у порушенні угоди.

Концепт Персонального мандата має на увазі запровадження електронного голосування, подібного до того, яке вже діє в деяких країнах. В такому разі “припинення кредитування” може відбуватися у такий же зручний спосіб, що й голосування: набрати відповідний персональний код на телефоні чи комп'ютері - і натискує клавішу enter. Коли кількість відкликаних голосів сягне критичної позначки (приміром, 15 чи 20 \%), мандат анулюється автоматично без втручання будь-яких проміжних інстанцій [29].

Об’єднавча ідея виходить з того, що ВРУ навряд ухвалить Закон про впровадження персонального мандата без тривалого ПОЗАсистемного тиску. Такий тиск може розпочати громадянська кампанія “За персональний мандат”, яка поступово консолідувала би значну частину громадянського суспільства, отже, i його структур. Подібна кампанія не потребує суттєвих витрат на функціонерів і агітацію: кожна громадська структура має змогу ініціювати створення місцевих осередків силами своїх активістів.

Співпраця із впровадження Мандата може стати спільним Проектом всіх соціальних та етнічних структур нації. Аби уникнути стартової конкуренції за ідейний прапор консолідації, Спільний Проект вчинив за гаслом “зроби і відійди”: заявив про відмову від гіпотетичної участі в ор- 
ганізаційному етапі творення об'єднавчої платформи [30].

Привабливість Персонального мандата як можливої об'єднавчої мети знаходить підтвердження як в експертному, так і в політичному середовищі. Першим з відомих політиків, який публічно визнав і особисто обгрунтував суспільну потребу в Персональному мандаті, став Михайло Саакашвілі. У відеозверненні влітку 2018 року він сформулював суть новації своїми словами: виборцям не треба вірити політикам треба їх контролювати під загрозою негайного відкликання [31]. Ролик 3 цією промовою отримав 147 тис. переглядів та 3517 поширень.

На подальших етапах консолідації доступність та прозорість ініціативи може забезпечити застосування IT-платформи типу LiquidFeedback (поточний зворотний зв'язок). Прийнятність подібної платформи засвідчує досвід іiі застосування деякими європейськими партіями в Німеччині, Іспанії, Швеції.

Висновки і перспективи подальших досліджень. Роль українського архетипу, як джерела європейської безпеки, випливає з провідної духовної позиції України в європейських процесах. Суть нового явища французький філософ Бернар-Анрі Леві зафіксував метафорою: “...існує ідея Європи, яку тепер несе в собі Украіна”.

Відновити систему міжнародної безпеки неможливо без подолання внутрішньої кризи Західної цивілізації. Суттевим гальмом на шляху сталого розвитку стали олігархічні наслідки, які руйнують основу демократії - суспільну довіру. Найбіль- ше від цієї біди потерпає Україна, де, на думку першого віце-президента НАН України Володимира Горбуліна, проблема набула вже екзистенційної гостроти.

Антикорупційна кампанія фiнансового і дипломатичного тиску на владу донорів і союзників, пряма участь їх представників у внутрішніх процесах позитивного перелому не принесли.

Інший погляд на вирішення проблеми пропонує міждисциплінарна група незалежних дослідників Спільний Проект. Авторська гіпотеза виходить з урахування відомої властивості систем: вони мають механізми захисту і самовідтворення в разі пошкоджень. Зокрема, наявна в Україні олігархічна система увібрала в себе ключові ланки державного апарату і місцевих органів самоуправління. Тому вони не можуть працювати на шкоду Системі, i автоматично видають імітацію.

Для заміни чинної системи і одночасного творення Іншої системи потрібен потужний ПОЗАсистемний суб'єкт - масова позапартійна платформа. Беручи до уваги наявність "майданного" архетипу українців, оздоровчим суб'єктом може стати відповідальний клас, який зараз переживає стадію самоусвідомлення. Консолідація громадянського суспільства може відбутися на об'єднавчій Платформі - відповідно до думки Ортега-і-Гассети про спільний проект майбутнього, який лише і здатен об'єднати сучасну націю.

Візійним проектом такої Платформи може стати концепт Позитивного сценарію Спільного Проекту. За висновком незалежної Агенції 
досліджень системних технологій Сценарій запропонував конструктивні кроки до зближення громадських рухів і спільнот з метою їх консолідації у протистоянні олігархічній Системі і прискорення здійснення реформ.

Публікація може розглядатися як один з нових підходів до безпечного і сталого розвитку в умовах цивілізаційних зрушень. Авторська гіпотеза передбачає, що в середньостроковій перспективі (до 2030 р.) європейські країни можуть збудувати, разом 3 Україною, нову безпекову систему. Для цього варто опанувати новітні уявлення про сучасний стан розвитку людства і технології роботи 3 Майбутнім, внести суттєві корективи до публічного урядування.

Спільність деяких українських і західноєвропейських проблем дає підстави для міжнародної консолідації на подолання кризи. 3 українського боку на спільний розгляд можна висунути пропозиції Спільного Проекту. Наприклад, ідею мерЕжаної демократії як нової політичної Ідеї, якої, на думку соціолога Етьєна Балібара [32] наразі не вистачає Європі.

Стартовим пакетом масового руху в Україні пропонується консолідація громадянського суспільства навколо впровадження Персонального мандата. Концепт цієї правової новації підтримало чимало українських інтелектуалів, першим з яких був відомий правознавець-конституціоналіст професор Віктор Мусіяка. Нещодавно новація зацікавила і професора Університету Париж V Сорбонна, засновника Центру досліджень сучасності повсякденності Мiшеля Маффесолі.
Принаймні, авторський концепт врахував як заклик західних інтелектуалів допомогти українцям зараз, так і їхні сподівання на допомогу українців у “побудові нової Свропи більш справедливого світу”.

\section{СПИСОК ВИКОРИСТАНИХ ДЖЕРЕЛ}

1. Хавронин А. Итоги интернет-борьбы с плагиатом в Германии [Электронный ресурс] / Радіо Свобода, 14 Июль 2011. - Режим доступа: http://www.svobodanews. $\mathrm{ru} /$ content/transcript/24266277. html

2. Тертичний О. Камо грядеши? До мережевої демократії, звичайно ж! [Електронний ресурс] // Українська правда, 26 листоп. 2010. - Режим доступу: https://www.pravda.com. ua/columns/2010/11/26/5601111/

3. Повещенко Г., Чеховий Ю. Математична модель структурної еволюції суспільних продуктивних сил [Електронний ресурс] // Журнал Ін-ту соціології НАН України "Соціологія: теорія, методи, маркетинг”. - 2001. - № 3. - С. 41-59. Режим доступу: http://i-soc.com.ua/ journal/N3_2001r_3.pdf.

4. Голіната А. Обама: "Народ України не вийшов на вулиці через якусь закордонну змову...” [Електронний ресурс] / Українська редакція Радіо Голос Америки, 20 верес., 2016. Режим доступу: https://ukrainian. voanews.com/a/vystup-obamy-nageneralniy-asamblei-oon/3517249. html

5. Immanuel Wallerstein "The Fantactic Success of Occupy Wall Street" // Особиста сторінка Імануела Валерстайна. 19 жовт. 2011 [Електронний ресурс]. - Режим доступу: /www. zcommunications.org/the-fantastic- 
success-of-occupy-wall-street-byimmanuel-wallerstein\#

6. Афонін Е. А., Мартинов А. Ю. Архетипи індивідуального і колективного в моделі універсального соціального циклу // Публічне урядування (Public management). - червень 2018 (спецвип.). - № 4 (14). - К.: ДП “Вид. дім “Персонал”, 2018.

7. Support Ukrainians and they can helpus build a fairer Europe [Електронний ресурс] / The Guardian, Friday 3 January 2014. - Режим доступу: https://www.theguardian. com/world/2014/jan/03/supportukrainians-build-fairer-europe

8. Бернар Анрі-Леві. Україна носить ідею Свропи [Електронний ресурс] / Громадське радіо. - 20 лют., 2015. - Режим доступу: http:// hromadskeradio.org/2015/02/20/ bernar-anri-levi-ukrayina-nositideyu-yevropi/

9. Тертичний О. В. Концепція мережаної демократії як позитивний форсайт-сценарій / II Конгрес Соціологічної асоціації України. - Х., 2013. Тези доповідей. - С. 374-375.

10. Гаврилишин Б. За два роки в Украіні почнеться економічне диво [Електронний ресурс] // Сайт Ініціативи 1 грудня. 4 лютого 2015. Режим доступу: http://1-12.org. ua/2015/02/04/3379

11. Горбулін В. Чи є життя після Мінська? [Електронний ресурс] //Дзеркало тижня. 12 лютого 2016 р. Режим доступу: https://dt.ua/ internal/chi-ye-zhittya-pislyaminska-mirkuvannya-schodoneminuchostineobhidnihzmin.html?fb clid=IwAR1n8ezLo18H9qcJeXVFKy 7cCGvU122R52jhJu9yZPQMlvvBx4 K0vXreOmg

12. Тертичний О. Чотири Бачення майбутнього України. [Електронний ресурс] // ФБ-група Спільний Проект, Файли 7 липня 2015. - Ре- жим доступу: https://www.facebook. com/notes /спільний-проект/чотири-бачення-майбутнього-україни/734020860057143

13. Суший О. В., Бєльська Т. В., Тертичний O. В. Стратегія виходу України із системної кризи // Український соціум. - 2014. - № 2 (49).

14. Про Стратегію сталого розвитку “Україна - 2020". Указ Президента України [Електронний ресурс] / Платформа Верховної Ради України. - Режим доступу: http://zakon4. rada.gov.ua/laws/show/5/2015\#n10

15. Проект Суспільного договору [Електронний ресурс] / сайт “Новий суспільний договір”. - Режим доступу: https://sdukr.com/contract $\backslash$

16. Форсайт економіки України: середньостроковий (2015-2020 роки) i довгостроковий (2020-2030 роки) часові горизонти / наук. керівник проекту акад. НАН України М. З. Згуровський. - К. : НТУУ “КПІ”, 2015.

17. Горбулін В. Вулканічний синдром // Дзеркало тижня. - 15 черв. 2018 р.

18. Тертичний O. Ukrainian dream: коридор принципово нових можливостей [Електронний ресурс] // Українська правда. - 8 верес. 2010. - Режим доступу: https://www.pravda.com. ua/columns/2011/12/25/6841586/

19. World-Low $9 \%$ of Ukrainians Confident in Government [Електронний ресурс] // Сайт Gallup MARCH 21, 2019. - Режим доступу: https://news.gallup.com/ poll/247976/world-low-ukrainiansconfident-government.aspx

20. Дубровсъкий В., Лаф Дж. Україна має зосередитися радше на запобіганні корупції, а не покаранні. Великий антикорупційний аналіз [Електронний ресурс] /платформа VoxUkraine березень 5, 2019. - Peжим доступу: https://voxukraine. org/uk/ukrayina-maye-zosereditisya- 
na-zapobiganni-koruptsiyi-a-nepokaranni-velikij-antikoruptsijnijanaliz/

21. Єрмолаєв А. "Країною керує корпорація. Державні інститути приватизовано" [Електронний ресурс] // Дзеркало тижня. -7 лют., 2014. - Режим доступу: http:// gazeta.dt.ua/socium/andriyyermolayev-krayinoyu-keruyekorporaciya-derzhavni-institutiprivatizovano-_.html

22. Рецензія на громадський проект "Позитивний сценарій” [Електронний ресурс] // Агенція досліджень системних технологій, 08.11.2017. ежим доступу: https://drive. google.com/file/d/1lVRf3QxGf8 22 K T 46pMU 7 hmy Lvp BdIRa/ view?fbclid=IwAR1hx3p9gi_qPel8C 3AomtFHTNvVpjh8aSFz2t0Pr0jwrp $\mathrm{TdCnPzH7wUo}$

23. Яковенко Ю. І. Соціологія в сучасній Україні: чи є рух вперед? [Електронний ресурс] /Міжнародний науковий форум: соціологія, психологія, педагогіка, менеджмент. 2012. - Режим доступу: Mnf_2012_8_3

24. Тертичний O. Ентелехія як моделіст позитивного сценарію // Матеріали II Всеукраїнської наукової конференції 24-25 берез. 2017 p. - Ч. I. - С. 62. Дніпро, 2017.

25. Волонтерський рух: світовий досвід та українські громадянські практики: аналіт. доп. - К.: НІСД, 2015. $36 \mathrm{c}$.

26. Середній клас в Україні: уявлення і реалії [Електронний ресурс] / УЦЕПД ім. Олександра Разумкова, с. 11. - Режим доступу: http://razumkov.org.ua/uploads/ article/2016_Seredn_klas.pdf

27. Буравой М. За пуббличную социологию [Электронный ресурс] / пер. А. Балджи; под ред. Е. Ярской-Смирновой и П. Романова. -
Режим доступа: http://publicsphere. narod.ru/Burawoy.pdf

28. Тертичний $O . \quad B . \quad$ Український шлях: до прийдешньої перемоги / О.В.Тертичний // Суспільно-політичні процеси. - Вип. 3 (10). 2018. - C. 319-366.

29. Тертичний O. В. Персональний мандат / О. В. Тертичний // Актуальні проблеми сучасного суспільства в фокусі соціології: Матеріали всеукраїнської науково-практичної конференції, м. Київ, 19 берез. 2014 р. - К.: Міленіум, 2014. C. 45 .

30. Персональний мандат як мережа національної консолідації [Електронний ресурс] // Спільний Проект, 2017. - Режим доступу: https://drive.google.com/ file/d/1 hvvyLA0cmwktrBYMO zLOlO 88iDZz7/view?usp=sharing

31. Saakashvili M. Нам нужен инструмент быстрого исправления ошибок [Электронный ресурс] // Facebook блог Mikheil Saakashvili. Режим доступа: https://www. facebook.com/SaakashviliMikheil/ videos/2002915003072204/

32. Balibar E. "Gilets jaunes: le sens du face à face" [Електронний ресурс] // Mediapart, le blog de Etienne Balibar, 13 DÉC. 2018. - Режим доступу: https://blogs.mediapart.fr/etiennebalibar/blog/131218/gilets-jaunes-lesens-du-face-face

\section{REFERENCES}

1. Khavronin A. (July 14, 2011). Itogi internet-borby s plagiatom v Germanii [Results of the Internet fight against plagiarism in Germany]. www.svobodanews.ru. Retrieved from http:// www.svobodanews.ru/content/transcript/24266277.html [in Russian].

2. Tertychnyi O. (2010, November 26). Kamo hriadeshy? Do merezhevoi 
demokratii, zvychaino zh! [Quo Vadis? To network democracy, of course!]. Ukrainska pravda Ukrainian Truth. Retrieved from https://www.pravda.com.ua/columns/2010/11/26/5601111/ [in Ukrainian].

3. Poveshchenko H., Chekhovyi Yu. (2001). Matematychna model strukturnoi evoliutsii suspilnykh produktyvnykh syl [Mathematical model of structural evolution of social productive forces]. Zhurnal Instytutu sotsiolohii NAN Ukrainy "Sotsiolohiia: teoriia, metody, marketynh" - Journal of the Institute of Sociology of the National Academy of Sciences of Ukraine "Sociology: Theory, Methods, Marketing", 3, 41-59. Retrieved from http://i-soc.com.ua/ journal/N3_2001r_3.pdf [in Ukrainian].

4. Holinata A. (September 20, 2016). Obama: "Narod Ukrainy ne vyishov na vulytsi cherez yakus zakordonnu zmovu..." [Obama: "The people of Ukraine did not go out on the street because of some kind of foreign conspiracy ...”]. ukrainian.voanews.com. Retrieved from https://ukrainian. voanews.com/a/vystup-obamy-nageneralniy-asamblei-oon/3517249. html [in Ukrainian].

5. Wallerstein I. (October 19, 2011). The Fantactic Success of Occupy Wall Street. www.zcommunications. org. Retrieved from www.zcommunications.org/the-fantastic-successof-occupy-wall-street-by-immanuelwallerstein\# [in English].

6. Afonin E. A., Martynov A. Yu. (2018). Arkhetypy indyvidualnoho i kolektyvnoho v modeli universalnoho sotsialnoho tsyklu [Archetypes of Individual and Collective in the Model of the Universal Social Cycle]. Publichne Uriaduvannia - Public Management, 4 (14), 18-33 [in Ukrainian].
7. Support Ukrainians and they can helpus build a fairer Europe. (January 3, 2014). www.theguardian.com. Retrieved from https://www.theguardian.com/world/2014/jan/03/supportukrainians-build-fairer-europe [in English].

8. Makarov Yu. (February 20, 2015). Bernar Anri-Levi: Ukraina nosyt ideiu Yevropy [Henri-Levi Bernard: Ukraine Bears the Idea of Europe]. hromadskeradio.org. Retrieved from http://hromadskeradio. org/2015/02/20/bernar-anri-leviukrayina-nosit-ideyu-yevropi/ [in Ukrainian].

9. Tertychnyi O. V. (2013). Kontseptsiia merezhanoi demokratii yak pozytyvnyi forsait-stsenarii [The concept of network democracy as a positive forsite script]. II Konhres Sotsiolohichnoi asotsiatsii Ukrainy $-2^{\text {nd }}$ Congress of the Sociological Association of Ukraine: Proceedings of reports. (p. 374-375). Kharkiv [in Ukrainian].

10. Havrylyshyn B. (February 4, 2015). Za dva roky v Ukraini pochnetsia ekonomichne dyvo [An economic miracle will begin in Ukraine in two years]. 1-12.org.ua. Retrieved from http://1-12.org.ua/2015/02/04/3379 [in Ukrainian].

11. Horbulin V. (February 12, 2016). Chy ye zhyttia pislia Minska? [Is there life after Minsk?]. dt.ua. Retrieved from https://dt.ua/internal/chi-yezhittya-pislya-minska-mirkuvannya-schodo-neminuchostineobhidnihzmin.html?fbclid=IwAR1n8ezLo 18H9qcJeXVFKy7cCGvU122R52jh Ju9yZPQMlvvBx4K0vXreOmg [in Ukrainian].

12. Tertychnyi $O$. (July 7, 2015). Chotyry Bachennia maibutnoho Ukrainy [Four Visions of the Future of Ukraine]. www. facebook.com. Retrieved from https:// www.facebook.com/notes/spilnyiproekt/chotyry-bachennia-maibut- 
noho-ukrainy/734020860057143 [in Ukrainian].

13. Sushyi O. V., Bielska T. V., Tertychnyi O. $V$. (2014). Stratehiia vykhodu ukrainy iz systemnoi kryzy [Strategy of Outcome of Ukraine from System Crisis]. Ukrainskyi sotsium - Ukrainian society, 2 (49), 128-134 [in Ukrainian].

14. Ukaz Prezydenta Ukrainy "Pro Stratehiiu staloho rozvytku "Ukraina-2020" : id 12.01.2015, № 5/2015 [Decree of the President of Ukraine "On the Strategy of Sustainable Development "Ukraine 2020" from 12.01.2015, № 5/2015]. zakon.rada.gov.ua. Retrieved from http://zakon4.rada. gov.ua/laws/show/5/2015\#n10 [in Ukrainian].

15. Proekt Suspilnoho dohovoru [Draft Public Contract]. sdukr.com. Retrieved from https://sdukr.com/contract [in Ukrainian].

16. Zghurozskyi M. Z. (2015). Forsait ekonomiky Ukrainy: serednostrokovyi (2015-2020 roky) i dovhostrokovyi (2020-2030 roky) chasovi horyzonty [Foresight of Ukraine's economy: medium-term (2015-2020) and long-term (2020-2030) time horizons]. Kyiv: NTUU "KPI" [in Ukrainian].

17. Horbulin V. (June 15, 2018). Vulkanichnyi syndrom [Volcanic syndrome]. Dzerkalo tyzhnia - Mirror of the week [in Ukrainian].

18. Tertychnyi O. (September 08, 2010). Ukrainian dream: korydor pryntsypovo novykh mozhlyvostei [Ukrainian dream: a corridor of fundamentally new opportunities]. Ukrainska pravda - Ukrainian Truth. Retrieved from https://www.pravda.com.ua/ columns/2011/12/25/6841586/ [in Ukrainian].

19. Bikus Z. (March 21, 2019). WorldLow $9 \%$ of Ukrainians Confident in Government. news.gallup.com. Retrieved from https://news.gallup. com/poll/247976/world-low-ukrainians-confident-government.aspx [in English].

20. Dubrouskyi V., LafJ. (March 5, 2019). Ukraina maie zoseredytysia radshe na zapobihanni koruptsii, a ne pokaranni. Velykyi antykoruptsiinyi analiz [Ukraine should focus more on preventing corruption, not punishment. Big Anticorruption Analysis]. voxukraine.org. Retrieved from https://voxukraine.org/uk/ukrayinamaye-zosereditisya-na-zapobigannikoruptsiyi-a-ne-pokaranni-velikijantikoruptsijnij-analiz/ [in Ukrainian].

21. Kotliar A. (February 7, 2014). Yermolaiev Andrii: "Krainoiu keruie korporatsiia. Derzhavni instytuty pryvatyzovano" [Yermolayev Andriy: "The country is governed by a corporation. State institutions are privatized"]. dt.ua. Retrieved from https://dt.ua/ socium/andriy-yermolayev-krayinoyu-keruye-korporaciya-derzhavniinstituti-privatizovano-_.html [in Ukrainian].

22. Romanov M. M. (November 8, 2017). Retsenziia na hromadskyi proekt "Pozytyvnyi Stsenarii" [Review of the public project "positive scenario"]. drive.google.com. Retrieved from https://drive.google.com/file/d/1lV Rf3QxGf822nKT46pMU7hmyLvpBdIRa/view?fbclid=IwAR1hx3p9gi qPel8C3AomtFHTNvVpjh8aSFz2t0Pr0jwrpTdCnPzH7wUo [in Ukrainian].

23. Yakovenko Yu. I. (2012). Sotsiolohiia v suchasnii Ukraini: chy ye rukh vpered? [Sociology in modern Ukraine: Is there movement ahead?]. Mizhnarodnyi naukovyi forum: sotsiolohiia, psykholohiia, pedahohika, menedzhment - International scientific forum: sociology, psychology, pedagogy, management, 8, 5-32 [in Ukrainian]. 
24. Tertychnyi O. (2017). Entelekhiia yak modelist pozytyvnoho stsenariiu [Entelechy as a modelist of a positive scenario]. Ukraina v humanitarnykh i sotsialno-ekonomichnykh vymirakh Ukraine in Humanitarian and SocioEconomic Dimensions: Proceedings of the $2^{\text {nd }}$ All-Ukrainian Scientific Conference March. (Vols. 1). Dnipro [in Ukrainian].

25. Volonterskyi rukh: svitovyi dosvid ta ukrainski hromadianski praktyky [Volunteer Movement: World Experience and Ukrainian Civic Practices]. (2015). Kyiv: NISD [in Ukrainian].

26. Rachok, A., et. al. (2016). Serednii Klas v Ukraini: Uiavlennia i Realii [The Middle Class in Ukraine: Views and Realities]. Kyiv: UTsEPD imeni Oleksandra Razumkova. razumkov. org.ua. Retrieved from http://razumkov.org.ua/uploads/article/2016 Seredn_klas.pdf [in Ukrainian].

27. Burazoy M. (n.d.). Za publichnuyu sotsiologiyu [For public sociology]. (A. Baldzhi, Trans). E. YarskayaSmirnova, P. Romanov (Eds.). Retrieved from http://publicsphere. narod.ru/Burawoy.pdf [in Russian].

28. Tertychnyi O. V. (2018). Ukrainskyi Shliakh: Do Pryideshnoi Peremohy [Ukrainian Way: To Future Win]. Sus-
pilno-Politychni Protsesy Vypusk Social-Political Processes, 3 (10), 319-366 [in Ukrainian].

29. Tertychnyi O. V. (2014). Personalnyi Mandat [Personal Mandate]. Aktualni problemy suchasnoho suspilstva v fokusi sotsiolohii - Actual problems of modern society in the focus of sociology: Proceedings of the All-Ukrainian Scientific and Practical Conference. Kyiv: Milenium [in Ukrainian].

30. Personalnyi mandat yak merezha natsionalnoi konsolidatsii [Personal mandate as the netherlands consolidation network]. (2017). drive.google.com. Retrieved from https://drive.google.com/ file/d/1 hvvyLA0cmwktrBYMO zLOlO_88iDZz7/view?usp=sharing [in Ukrainian].

31. Saakashvili M. (n.d.). Nam nuzhen ynstrument bustroho yspravlenyia oshybok [We need a quick fix tool]. www. facebook.com. Retrieved from https://www.facebook.com/SaakashviliMikheil/videos/2002915003072204/ [in Russian].

32. Balibar E. (December 13, 2018). Gilets jaunes: le sens du face à face. blogs. mediapart.fr. Retrieved from https:// blogs.mediapart.fr/etienne-balibar/ blog/131218/gilets-jaunes-le-sensdu-face-face [in French]. 